\title{
UNIPOP PROJECT: Transcending frontiers of the legal Amazon for knowledge
}

\author{
PROJETO UNIPOP: Transcendendo fronteiras da Amazônia legal em prol do \\ conhecimento
}

\author{
Elisangela Dias Brugnera \\ Universidade do Estado de Mato Grosso/ Faculdade de Ciências Exatas e \\ Tecnológicas - FACET - Brasil \\ brugnera.elisangela@unemat.br \\ Roseli Ribeiro Mamede \\ Universidade do Estado de Mato Grosso - Brasil \\ mamede.unemat@hotmail.com \\ Bernardo Poyer Gabe Américo \\ Universidade do Estado de Mato Grosso - Brasil \\ bernardopoyer00@gmail.com \\ Carla Eduarda Alvez Izidório \\ Universidade do Estado de Mato Grosso - Brasil \\ c.izidorio101@gmail.com \\ Felipe José Moraes de Oliveira \\ Universidade do Estado de Mato Grosso - Brasil \\ felipejosemoraes77@gmail.com
}

Fecha recepción: 10-03-2020

Páginas 98-108

Fecha aceptación: 20-05-2020

\begin{abstract}
.
The University is characterized as a space of human formation, being a reference institution in relation to the construction of knowledge, education, technological and social development. In this context, universities obey the inseparability between teaching research and extension; Thus we seek to present the extension project Popular University - UNIPOP that develops activities with the University of the State of Mato Grosso - UNEMAT, Sinop Campus that has consolidated itself as a space of confluence, debate, development, socialization and diffusion of diverse knowledge. The objective is to show the importance of university extension, through extension project actions, aimed at offering short courses in various areas of knowledge. The procedures adopted in this research were subsidized by qualitative methods, to obtain the data, we used an open questionnaire applied to the students who participated in the offered courses. The results point out the importance of extension actions developed by the university for the population in general, being relevant and significant for the construction of knowledge, as well as contributing to the knowledge of the academy to be socialized and the participating public of the taught mini-courses have one more space. that enables to build and consolidate varied knowledge.
\end{abstract}

Keywords: extension, knowledge, teaching, socialization 


\section{Resumo.}

A Universidade é caracterizada como um espaço de formação humana, sendo uma instituição de referência em relação à construção do conhecimento, educação, desenvolvimento tecnológico e social. Nesse contexto, as universidades obedecem à inseparabilidade entre a pesquisa pedagógica e a extensão; Assim procuramos apresentar o projeto de extensão Universidade Popular - UNIPOP que desenvolve atividades com a Universidade do Estado do Mato Grosso - UNEMAT, Campus Sinop que se consolidou como um espaço de confluência, debate, desenvolvimento, socialização e difusão de conhecimentos diversos. O objetivo é mostrar a importância da extensão universitária, através de ações de projetos de extensão, visando oferecer cursos de curta duração em diversas áreas do conhecimento. Os procedimentos adotados nesta pesquisa foram subsidiados por métodos qualitativos, para obtenção dos dados, utilizamos um questionário aberto aplicado aos alunos que participaram dos cursos oferecidos. Os resultados apontam a importância das ações de extensão desenvolvidas pela universidade para a população em geral, sendo relevantes e significativas para a construção do conhecimento, além de contribuir para o conhecimento da academia a ser socializada e o público participante dos minicursos ministrados ter mais um espaço. que possibilita a construção e consolidação de conhecimentos variados.

Palavras-chave: extensão, conhecimento, ensino, socialização

\section{1.-Introduction.}

The activities of the Popular University - Unipop project were initiated in 2005, having as a public involved the community in general, seeking to bring Sinopense society closer to the State University of Mato Grosso UNEMAT - Campus of Sinop, mainly a rapprochement of the most needy communities socio-economically, but that have the will to overcome the conditions that are structurally placed, or that have been relegated. Knowledge, Knowledge presents itself as the path to overcoming inequalities and is therefore the option for their socialization, only for those who enter the university through the graduation path, in its selective vestibular form. In this context, the Unipop project arises with the purpose of encouraging community participation in the University's activities, with the primary objective of building in the University, through the project, a confluence of diverse knowledges that can be disseminated and socialized for the benefit of the Community through voluntary action. To know these that go from the University to the Community, from the Community to the University and from the Community to the Community.

The Unipop project offers the community several spaces of direct coexistence with the University world, opening space in a permanent way for the exercise of knowledge and search. This way, activities such as courses, lectures, guided visits to the University, cultural and literary presentations started to be developed, where the internal and external community was requested to volunteer services. This service has been expanded and concretized to the point that in several years the instituted 
activities have made possible the involvement of more than 5000 people. The courses offered promoted training activities that enabled the participants to acquire knowledge that helped them acquire or increase their family income. Their specific purpose is to build a University open not only to academics, but to the population in general, where people and groups can develop activities that go beyond the offer of undergraduate or graduate qualifications, participating in courses, lectures, debates, training and cultural presentations that can be developed both on campus and with the community through residents' associations or representative entities and groups.

The proposal of the Popular University Project that UNEMAT develops understands that it is its responsibility to act directly with the community and is based, as a priority, on the democratization of the community's access to its physical structure, its structure of human resources, equipment, materials and fundamentally of knowledge, thus being able to create a permanent link between the University and the Community, since UNEMAT, as a state university is a public institution, of all.

Its specific purpose is to build a University open not only to academics, but to the population in general, where people and groups can develop activities that go beyond the offer of undergraduate or graduate qualifications, participating in courses, lectures, debates, training and cultural presentations that can be developed both on campus and with the community through associations of residents or representative entities and groups, seeking inclusion of society in the University, so that, especially the needy communities may have the desire to access and access the University, in one way or another, bringing the University closer to the society it is intended for. In this context, the objective of this research is to show the importance of university extension, through actions of the Unipop extension project, focused on offering minicourses from various areas of knowledge. In order to reach the general objective, we have listed some specific objectives: To increase the chances of access of the Community to the University; To create, together with the University, activities that may bring society closer in the search and diffusion of knowledge; To elaborate a schedule so that these activities are integrated in the structural organization of the University; To open each semester around 20 varied courses, involving at least 500 people; To issue certificates to the formators/trainees (teachers, instructors and students) at the end of each course and To support with specific actions the permanence of society in the proposed activities.

\section{2.-Development.}

2.1.-Regulation of extension, contributions and benefits between Unemat and society.

The university extension is already developed in public universities, being one of its pillars: Teaching, Research and Extension. As a legal framework we have the Federal Constitution of 1988 in Art 207 - "Universities enjoy didactic-scientific, administrative and financial management autonomy, and will obey the principle of indissociability between teaching, research and extension". In this context institutionalized actions 
have been developed in the form of centers, nuclei, programs and projects within higher education institutions.

Law No. 13,005 of June 25, 2014 of the National Education Plan (2014-2024) makes explicit in Strategy 12.7 the goal 12 "ensure at least 10\% (ten percent) of the total curriculum credits required for graduation in programs and projects for university extension, focusing its action, primarily, on areas of great social relevance. This law meets the Resolution of the National Council of Education (CNE) which addresses in its Resolution No. 07 of December 18, 2018, which establishes the Guidelines for Extension in Brazilian Higher Education and regulates the provisions of Goal 12.07 of Law No. 13.005/2014, which approves the National Education Plan - PNE 2014-2024. In this context, extension becomes mandatory in higher education courses, where students must meet at least $10 \%$ (ten percent) of the total course load in extension actions, allowing the effective integration of teaching, research and extension.

In this context, Unemat has been proposing actions that aim at integrating the external community to the institution, either through courses, events, seminars and others. In the website of the State University of Mato Grosso - Unemat we find the definition of university extension adopted by the institution, where it is configured, making it possible to better understand the trajectory of university extension, since it is the educational, cultural and scientific process that articulates teaching and research in an inseparable manner and enables the transforming relationship between the University and society. In such a way that it contemplates the national guidelines, regarding dialogical interaction, interdisciplinarity and interprofessionality, indissociability Teaching-Search-Extension, impact on the formation of the student and impact and social transformation (UNEMAT, 2020).

The University of the State of Mato Grosso also highlights the objectives it intends to achieve with the extension actions developed:

- To articulate teaching and research according to the demands of society, seeking the commitment of the university community to its interests and social needs;

- To contribute to the strengthening of the University's relations with society;

- To guarantee a conception of the academic space understood as all the environments inside and outside the University where the historical-social process takes place with its multiple determinations;

- To contribute to the economic, social and cultural development, prioritizing regional specificities;

- To encourage academic practice that contributes to the development of citizenship and improvement of the quality of life;

- To establish mechanisms of integration between academic knowledge and popular knowledge, aiming at the generation of new knowledge;

- To implement the process of socialization of academic knowledge;

- To contribute to the reformulation of the University's curricular conceptions and practices, as well as to the systematization of the knowledge produced ((UNEMAT, 2020). 
In this context, the university extension is conceived as a space for the integration of the university with society, a space for the diffusion of knowledge, where knowledge is produced and socialized, where informal knowledge is valued and integrated with scientific knowledge, promoting social transformation. According to Schmitz (1984, p.182), "one of the most practical ways of fulfilling the critical and creative role in the community is the extension activity". And in this aspect, the university must be present in society, attentive to the problems it is facing, just as the academic community in general must be inserted in this challenge, through the elaboration of actions that integrate the university with the community that surrounds it. The extension promoted by the university takes place through courses, lectures, cultural activities, assistance, advisory services, enterprises and many other forms. But these should benefit the university and the community, promoting the dissemination of knowledge and citizen formation.

Thus, in the same line of thought it meets what Gamboa $(2008$, p.119) states: "A theory is valid as it transforms practice, and practice is also true as it transforms theory. From this dialectic relationship emerges the principle of the validity of knowledge as a source of transformation of reality: knowledge to transform". We agree with the author, for the challenge is to integrate theory and practice into academic education, enabling the academic to experience in his formative process the integration of teaching-research and extension.

Ação Extensionista is part of the set of affirmative actions of UNEMAT, with a view to democratizing the permanence in higher education. It aims to show the importance of university extension, through extension project actions, aimed at teaching diverse areas, providing the expansion of knowledge.

We emphasize that the university extension has great importance in the formation of the academic, because it puts into practice actions learned in their academic training on behalf of society. The moment the academic comes into contact with society and proposes transformations there are transformations on both sides. And in this sense, we highlight Rocha apud Silva (2011) who considers that, the relationship between the university and the community is strengthened by the University Extension, by providing dialogue between the parties and the possibility of developing socioeducational actions that prioritize overcoming the conditions of inequality and exclusion that still exist. And, as it socializes and makes its knowledge available, it has the opportunity to exercise and make effective the commitment to improve citizens' quality of life. (ROCHA 2007 apud SILVA, 2011, p.2).

For the authors, these actions strengthen the relationship of the university with society and vice-versa, consequently both parties benefit and we also emphasize that the extension allows the student to develop a differentiated knowledge and at the same time makes a social intervention, bringing benefits to society. And second, Pozzobon and Busato (2009, p.9), emphasize that "the influence of the university in the development process of society is given by the active and critical presence, by the interference in the spaces of culture, politics, economy and technology. 
Consequently, university extension assumes its role and function by providing students and teachers with the opportunity to disseminate the knowledge produced at the university. Extension, allied to research and teaching, breaks down the barriers of the university classroom, leaving a closed environment, starting to exchange knowledge with the community, assuming an inter, multi and transdisciplinary role. In addition to promoting integration between research and teaching, extension promotes the integration of the academic with society in various ways, either by promoting service provision, offering courses, disseminating knowledge, among others. With the realization of the university extension, the student starts to relate formal and informal knowledge. And the academic's formative process will be through the interaction with the teachers, with the community and with their peers in a dialogical way.

The actions developed by Unipop project have already attended more than 5000 (five thousand) people since its conception, assuming its responsibility in the context of the integration of society with the university, having as a goal the socialization and dissemination of knowledge, in a free and voluntary way, in a permanent interaction as institution and society. The ecology of knowledge proposed by Boaventura Sousa Santos makes explicit a reality that can be experienced by the University, in the sense that knowledge is not something owned by a caste of technicians and doctors, but by the whole of society and that society itself can voluntarily socialize its knowledge, producing emancipation. Thus, the theoretical perspective adopted is that the University can be a space for the socialization of knowledges built within it, as well as a space for the socialization of technical or popular knowledges of the society itself.

Socialized knowledge is now used as a tool for emancipation, either by providing the opportunity to raise the level of schooling, or as a fundamental tool to ensure survival through know-how, which enables income generation. Experiences of the project itself show that the popular University has provided numerous participants with a technicalprofessional placement, which has guaranteed, in essential moments of personal, family and community life, the passage of situations of unemployment, lack of opportunity to a place of dignity, self-esteem and personal, professional and economic valorization. The empowerment and personal and community valorization are provided continuously, whether by a child who has access to a computer course, a capoeira course, or by young people who, outside of school and who had access to Unipop and went back to study, entering university, in addition to people who with a course such as bio-jewels, fabric painting, decoupage, among others, began to earn their livelihood and family support.

\section{3.-Methodology.}

The investigation procedure followed was a qualitative, exploratory research with a case study. For the qualitative aspect we used a semi-structured questionnaire applied to the whole population, and an open interview applied to the project implementers. In an interview with the interviewer and the interviewee. The first one adopts the conversation initiative, plans using specific instructions for each topic of interest and decides the moment the topic meets the objectives. The interviewee 
facilitates the information about the ape, the experience or the theme in question. In qualitative research the researcher is his main instrument and the natural environment is his source of data, the greatest concern of the research is with the research process itself. For Hernández, y De Barros (2018). Statistics allow reconnecting, analyzing, interpreting and presenting the information that is obtained in the project of a specific investigation; the next step is the elaboration of the statistical investigation plan and the definitive replacement of the data. This recovery consists of the observation and annotation procedures (Hernández, y De Barros, 2018, p.109).

We conducted our research at Universidade do Estado de Mato Grosso - UNEMAT, Sinop Campus in the State of Mato Grosso-Brazil, located in the Amazon Legam, 500 $\mathrm{km}$ from the capital of the state and the various courses offered by the project in 2018. Where we developed the Unipop Project, in which it develops its actions in the Imperial campus of Unemat de Sinop, serving the population of its surroundings, offering several courses of short duration. And regarding the selection process of the participants, who are our research subjects here, it is through a biannual divulgation in digital and television media, in which the courses that will be offered are informed so that the population in general can have access to this information and come to participate. As for the execution of the project's actions, they are mostly concentrated on Saturday, as we face difficulties such as physical space in the institution for the allocation of more rooms to offer short courses, as during the week undergraduate courses are offered. Since the institutionalization of Unipop Project in 2012 until the current days, more than five thousand people have already participated in the activities and actions developed by the project. The choice to investigate the year 2018 was due to the fact that the registrations were offered in an online way, which enabled a more efficient data collection. We used all the polution that are the participants of the project registered in the year 2018 with a total of 751 students from the community, so our show coincides with the population.

According to Lüdke and André (1986, p. 17), a case study is "always well delimited and should have its outlines clearly defined in the development of the study". This should be applied when the researcher is interested in researching a particular, unique situation. According to Hernández, y De Barros (2018), in the case study the researcher usually analyzes different opinions and points of view of the individuals participating in the research, which allows him to understand the complexity of the phenomenon studied. In our case, this fits our research because we are analyzing the actions of a specific Unipop extension project. The activities of the Unipop project are developed through actions of survey of community and social demands by the coordination and scholarship holders and made available to instructors, monitors and volunteers. Another option is the development of volunteer actions by the teachers, academics and community themselves who decide for the protagonism in the participation and socialization of knowledge and knowledge as something not reserved only for themselves (Hernández, y De Barros, 2018, p.1011).

The implementation of this policy, which articulates actions under development with new actions, will have a procedural character and presupposes its follow-up, aiming 
at constant evaluation, as well as possible reorientations that are necessary to ensure the achievement of its objectives, which unfold into goals and actions foreseen before, during and after the entrance of the Community at the Popular University.

The courses are proposed based on the survey of these community and social demands, and may last from 20 to 80 hours depending on the course and the content to be worked on.

\section{4.-Analysis and Discussions.}

An analysis of the data obtained from the Unipop project in the year 2018, mainly about the courses that were offered in this period, and that had an average duration between 20 and 40 hours, given by volunteer and academic professors offered by UNEMAT, showed that in the year 2018, the project attended 751 students from the community, of these 572 were female and 179 male. Students from 12 to 50 years of age participated in the courses.

We observed that among the participants of the research they are available in several age groups. We can say then that in the Unipop project there is participation of all age groups present in the community, from children, youth, adults and people with more advanced age. This year we observed that the largest number of participants is in the adult age group. The following table shows the profile of the survey participants by age group, and also a description by gender:

Table 01.-Demonstration of Participants by Age Group and Gender.

\begin{tabular}{|c|c|}
\hline Age group & Quantity of participant \\
\hline Under 12 years & 12 participants \\
\hline 13 to 18 years & 166 participants \\
\hline 19 to 40 years & 374 participants \\
\hline 41 to 50 years & 163 participants \\
\hline Over 50 years & 36 participants \\
\hline Total & 751 students in the community. \\
\hline Female & 172 participants \\
\hline Sex Male & \\
\hline
\end{tabular}

Source: own.

During the research, we sought to know the level of schooling of the participants. We found that the community has a large participation in the project, since 390 participants of the UNIPOP project, are not attending higher education level, that is, are members of the community outside the college. Of these 109 participants have incomplete elementary schooling, 54 have completed elementary schooling, 115 have completed elementary schooling, and 112 have completed elementary schooling. Another point that we consider important to contribute is the family income ofUnipop project participants, in a large majority of 426 participants answered that the family income is between 2 and 3 minimum w ages, 262 participants declared that the family 
income is of one minimum $\mathrm{w}$ age and only 64 participants declared having family income of 4 minimum $w$ ages.

In this context, we realize the social function of the project, because all courses offered regardless of the workload or area of knowledge are free to society, without any charge or fee. We affirm this, because we carry out a search of values in the market and most of our courses would cost an average of $R \$ 280,00$ reais. For example, the basic computer course would be around $R \$ 280,00$ reais, without registration fee and material, which would make it unfeasible for many participants to take the training courses. Another aspect to be highlighted is related to the participants of the project who are students of various grades, seeking improvement in the most diverse areas of knowledge. The evasion of the courses is considered low, since the majority, i.e. $70 \%$ of the enrolled participants finish the courses. The main factors observed in the evasion of courses were that many times the student enters the job market, and due to time incompatibility, they abandon the course, another factor is the displacement to the university and some students reported familiar factors for the dropout in the courses.

According to the data collected and carrying out an analysis of the UNIPOP project, it was possible to verify some factors in which we will report the five (05) most relevant, such as:

1.- Educational interaction: better relationship between teacher and students: the student starts to take the lead in his formation and the teacher tends to be more guiding in the student's formation process.

2.- Interdisciplinary need: knowledge tries to be transdisciplinary and multidisciplinary, there is a better contextualization of the reality of the community.

3.-Improvement in the formative process: extension is now seen as a formative space by academics, and they begin to use the spaces for reflection of their own formative process.

4.-Social formation: the activities are born from social demands, and there is no specific type of financing for these extension actions.

5.-Professional qualification: the courses offered by the project are seen by the community as an accessible and inexpensive form of quality professional qualification.

In this sense, the characteristics of educational training implemented in the project aim to enable participants to position themselves in the labour market. And for this, both educational and professional qualifications are needed in order to develop skills and specialize in certain areas in order to best perform their duties. Currently, the UNIPOP project is part of the Centro de Ensino Pesquisa e Extensão -CEPEC (Research and Extension Teaching Center) (created in 2017) of Unemat at the Sinop Campus, being a reference in extensionist actions. Through the project we seek to make a difference both in the educational field that belongs to the university and in the social field. 


\section{4.-Conclusions.}

The public university is committed to social problems, cultivating education, training the citizen as a whole, being emancipatory and collaborating for the diffusion of various knowledge in society. Thus, the university extension is a formative process of students, technical professionals and teachers and has the capacity to interfere and transform their environment. In this context, we notice the expressive participation of the community in the actions developed by Unipop project, as well as the involvement of academics who voluntarily seek the project to put into practice contents learned during their initial formation, who started to use the spaces for reflection of their formative process. In this way, academics are able to go through transdisciplinary and multidisciplinary areas of knowledge, since the knowledge developed in the courses is contextualized with the reality of the community and the academic becomes an active agent in their initial formation process. The actions developed by Unipop project are born from social demands, and there is no specific type of financing for these extension actions, being totally free. These actions are perceived by the community as an accessible form of quality professional qualification. Due to these factors, we have reached our goal of presenting the importance of university extension, by means of Unipop extension project actions, focused on offering minicourses from several areas of knowledge.

The State University of Mato Grosso - UNEMAT, through the Normative Instruction No. $003 / 2019$ of November 2019, began to regulate the extension actions developed within the institution in accordance with what the National Education Council (20142024) establishes on the $10 \%$ (ten percent) of the total workload of the courses intended for extension actions. In this sense, concepts must be reformulated and reconstructed, the university must always be committed to social changes and as a consequence our values will be reorganized.

Finally, we can highlight that university extension is a two-way transformational process for both academia and society, it is an emancipatory and democratic process based on the construction of dialogues and respect for local culture and diversity. In conclusion of the analyses of the data collected, we can contact you that in the actions developed by the UNIPOP project, there is an integration between teaching, research and extension where the academic community is integrated into society, with an exchange of experiences and knowledge where both sides are favored. There is also the strengthening of the link between the university and society, promoting a social change in the community around it, it is the integration of the university with society. Therefore, the university extension is one of the tripods of the public university and it is of paramount importance for the academic and social formation of the university student, where he contributes to the improvement of society and also to the university that starts to have a social role, gaining credibility. 


\section{5.-References.}

Constituição Federal. (2019). Constituição Federal de 1988: Edição 2019 Atualizada pela Emenda 102/2019. Brasília: Editora Wohnrecht.

Gamboa, S. (2007). Pesquisa em educação: métodos e epistemologias. Chapecó: Argos.

Hernández, A., and De Barros, C. (2018). Metodología científica en humanidades. Jaén: Masquelibros, S.L.

Lüdke, M., \& André, M.E.D.A. (1986). Pesquisa em educação: abordagens qualitativas. São Paulo: EPU.

Lüdke, A., \& Marli E.D.A. (1986). Pesquisa em educação: abordagens qualitativas. São Paulo: EPU.

Mato Grosso (2011). Constituição do Estado de Mato Grosso. Cuiabá-MT: PUBLIAL Publicações Assembleia Legislativa, 2011. 128 p.

PNE - Plano Nacional de Educação. (2019). Diretrizes, metas e estratégias para a política educacional no período de 2014 a 2024. -Acessado em : http://pne.mec.gov.br/ data 02-12-2019.

Pozzobon, M.E., y Busato, M.A. (2009). Extensão Universitária: reflexão e ação. Chapecó, SC: Argos.

Schmitz, E.F. (1984). Caminhos da universidade brasileira: filosofia do ensino superior. Porto Alegre: Sagra.

Silva, M.G.M. (2011). Extensão: a face social da universidade? Campo Grande: Editora da UFMS.

UNEMAT. (2019). Universidade do Estado de Mato Grosso; Extensão e Cultura. Material disponível em: http://portal.unemat.br/?pg=site\&i=proec\&m=extensao-na-unemat . Conteúdo acessado em 02/12/2019. 